\title{
Demographic Processes in a Confined Population of the Common Vole ${ }^{1}$
}

\author{
Leszek NABAG€O
}

\begin{abstract}
Nabagło L., Demographic processes in a confined population of the common vole. Acta theriol., 26, 9: 163-183 [With 1 Table \& 9 Figs].

Studies were made on populations of Microtus arvalis confined in two-hectare fields of alfalfa and rape to ascertain to what degree rumbers and variations in demographic parameters depend on habitat factors connected with the species of crop, and to what degree on intrapopulation conditions. The numbers of voles were greater in the alfalfa field than in the rape. Differentiation in the level of numbers took place by means of variations in mortality rate. From August to October 1976 voles in the rape field exhibited reduction in reproduction potential and better capacity for survival than voles in the alfalfa field. The following periods were distinguished in respect of variations in numbers of the two populations over the course of a year: (1) increase; (2) stabilization; (3) winter decrease. The relation between rate of growth in numbers and density in successive periods was as follows: positive, negative and absence of relation. Intensity of recruitment was lesser in the population in the rape field during the stabilized period than that of increase in numbers, whereas in the alfalfa field it was similar in both periods. Mortality rate was higher in both populations during the stabilization period than during the increase period. Mortality among the voles was higher in winter in the alfalfa field. The controling character of the influence of the environment on the level of numbers and the regulating effect of density on mortality are discussed, as are also variations in turnover rate reflecting elements of the population maintenance expenditure, depending on habitat conditions.

[Inst. Ecol., Polish Acad. Sci., Dziekanów Leśny, 05-150 Łomianki,
\end{abstract} Poland].

\section{INTRODUCTION}

The studies so far carried out have not yet unequivocally defined the role of habitat factors in shaping variations in numbers of a population of Microtinae, either during the yearly cycle or over a period of several years. On the one hand Schultz (1969), Birney et al. (1976), Stenseth et al. (1977 a, b) drew up models of the functioning of Microtinae populations based mainly on the use the individual makes of the advantages of the biotic habitat. On the other hand the role of habitat factors, including food factors, in formation of population cycles, is usually overlooked by

1 Praca wykonana $w$ ramach problemu MR. II/15 
supporters of the stress hypothesis (Christian \& Davis, 1964) or geneticbehavioural hypcthesis (Chitty, 1964; Krebs \& Myers, 1974), on account of the small extent to which rodents make use of the accessible food supply (Grodziński et al., 1970; Trojan, 1970 and others). Andrzejewski (1975), however, considers that in the case of Clethrionomys glareolus (Schreber, 1780) food conditions play an important part in shaping the dynamics of population numbers, but such effects cannot be explained on the basis of a simple energy balance.

In studies on a population of Microtus arvalis (Pallas, 1779) much attention was paid to the role of habitat factors in forming the population dynamics of this species. Bashenina (1962), Ryszkowski et al. (1973) and other authors have shown that the occurrence and level of numbers of this species vary depending on the degree to which the habitat is changed and modified by human agency (e.g. land drainage and improvement, intensification of agricultural production, kind of crops, etc.). A large number of authors consider that changes in climatic and agrotechnical factors exert a decisive influence either directly or indirectly (by altering the food value of plants) on the development of a vole population (Martinet \& Meunier, 1969; Martinet \& Spitz, 1971; Gladkina, 1976). It would appear that the great number and variety of such influences prevented the formulation of an unambiguous theory describing changes in the demographic parameters of a vole population as the result of the effect of habitat factors.

The knowledge so far obtained on intrapopulation conditioning of the dynamics of numbers of $M$. arvalis is only fragmentary. What is known includes information on variations in the length of the reproduction period, the proportion of sexually active females and occurrence of winter reproduction in different phases of the population cycle (Adamczewska-Andrzejewska, 1974). Although the way in which the sex ratio changes over the course of a year is known (Frank, 1954; Poljakov, 1964 and others), the role of habitat factors in forming the sex structure of the common vole has not as yet been investigated. Adamczewska-Andrzejewska \& Nabagło (1977) found that increase in numbers is restricted in the middle of summer in a confined population of common voles, but the causes of this phenomenon have not yet been fully explained. There is also a lack of studies on the effect of the density of individuals on the processes of reproduction and mortality in a population under different habitat conditions. It is only when answers are found to the questions presented here that a basis will be provided for determining to what degree the level of numbers and variations in demographic parameters depend on the whole of habitat factors and to what degree on intrapopulation conditioning. 
The purpose of the present study was thus to examine the course of variation in numbers, in the processes of reproduction and mortality in a population of common voles living in crops differing in their food value. Endeavour was also made to ascertain which of these parametrs depend chiefly on the habitat in which the population lives and what part is played in their formation by the density of individuals.

\section{STUDY AREA, METHODS AND MATERIAL}

The object of these studies consisted of two isolated populations of $M$. arvalis living in neighbouring 2-hectare fields, one of alfalfa and the other of winter rape, situated at Łomna near Warsaw. The field area was flat with fairly uniform soil of the medium brown silt type.

The fields were enclosed by a wall of asbestos-cement tiles, $120 \mathrm{~cm}$ high, and sunk into the soil to a depth of $60 \mathrm{~cm}$. This wall isolated the alfalfa field population from that in rape field, and both populations from the alfalfa fields surrounding them. Each of the experimental fields was divided by a similar wall into four plots $0.5 \mathrm{ha}$ in size. There were ten holes $(10 \mathrm{~cm}$ in diameter) situated at ground level in the wall forming the boundary between different plots in the given crop. These holes enabled the voles to pass from one plot to another of the given crop.

The agrotechnical operations appropriate to each crop were carried out in the study fields during the course of the experiment. A factor differentiating the plots of each of the crops was the different amount of mineral fertilizers ${ }^{2}$ applied. Green mass was harvested from the alfalfa field twice a year (in June and August), while rape was harvested in July. After the rape had been harvested the field was ploughed and, after preparation, again sown with winter rape. There was a belt of uncultivated land overgrown with grass, approx. 1 meter wide, along the base of the wall surrounding each plot.

280 wooden boxes were arranged in a grid in each field in exactly the same way as in the studies made by Adamczewska-Andrzejewska \& Nabagło (1977), at intervals of 8-9.5 m. Three live-traps baited with oats were placed in each box.

In October 1975168 females and 192 males were introduced into the alfalfa field, which was then in its third year of cultivation of the same crop, and 148 females and 164 males into the rape field. Studies were carried out from December 1975 to July 1977 in the rape field, and up to September 1977 in the alfalfa field. Series of captures of the voles were made every week (except for the period from December 1975 to March 1976 and from December 1976 to April 1977, when they were made every two weeks). A trapping series consisted of four inspections of traps carried out every 12 hours. During the intervals between trapping series, one wheat rusk weighing about $40 \mathrm{~g}$ was placed in each box. The size of the rusk prevented its being carried away through the opening in the box, and thus formed a bait for the voles, encouraging them to visit the trapping sites during the time the traps were not in action.

Information on individuals was collected by the CMR method, marking the voles individually by toe clipping when caught for the first time (Naumov, 1951). At each capture a record was kept of the trapping date, kind of crop, number

2 The effect of crop fertilization on the development of the vole population will be presented in a separate paper. 
and sex of the individual and the sexual activity of females, assessed in accordance with the following criteria: closed vagina - inactive females; open vagina gestation; lactation - active females.

During the studies a total of 253 inspections were made of the traps in the alfalfa field and 213 in the rape field. A total of 30,194 captures of 7,115 individuals were made in the alfalfa field, and 17,515 captures of 3,603 individuals in the rape field.

\section{METHOD FOR ANALYSING MATERIAL}

The data collected were analysed by the calendar of captures method (Petrusewicz \& Andrzejewski, 1962; Andrzejewski, 1969). In the further part of this paper the population living in the alfalfa field is indicated by the symbol $A$, and in the rape field by $R$. Calculation was made separately for the trappable part of population $A$ and $R$ in successive weeks of the experiment:

1. number of individuals $\left(N_{t}\right)$,

2. rate of variations in population numbers $\left(\Delta N_{t}\right)$

3. rate of variations in population numbers per individual $\left(\Delta N_{t} / N_{t}\right)$,

4. number and percentage of individuals which were recruited into the population $\left(N_{p t}, \% N_{p t}\right)$, caught for the first time,

5. number and percentage of individuals disappearing from the population $\left(N_{u t}\right.$, $\% N_{u t}$ ), caught for the last time,

6. number and percentage of sexually active females $\left(N_{f a t}, \% N_{f a t}\right)$,

7. number and percentage of females in the population $\left(N_{f t}, \% N_{f t}\right)$,

8. course of the dynamic of numbers for population $R\left(N_{c t}\right)$, taking as the initial numbers $\left(N_{c_{0}}\right)$ those found for the population in the alfalfa field $\left(N_{0}\right)$, in accordance with the equation:

$$
N_{c t+1}=N_{c t}\left(1+\frac{\% N_{p t}-0 \% N_{u t}}{100 \%}\right) \text {, where }
$$

$\% N_{p t}, \% N_{u t}$ - percentage of individuals recruited or disappearing from the population in a given week, observed in population $R$,

9. Calculated values $N_{c t}$ for population $R$ were compared with the corresponding values $N_{t}$ for population $A$, the results obtained being given in percentage $\left(\% N_{c t}\right)$,

10. Significance of differences between population parameters were examined on the level of confidence of $\alpha \leqslant 0.05$ by means of:

- test for parallelism for parameters described by regression equations,

- Student $t$ test for parameters converted to an average value.

\section{RESULTS}

Observations were made to ascertain whether the wall dividing each of the crops into four parts was a factor isolating groups of individuals occupying the differently fertilized 0.5 ha plots of the given field. It was found that in more than one plot $13.01 \%$ 우 and $19.64 \%$ of $\delta$ were caught in population $A$ and $18.93 \%$ 우 and $24.47 \%$ $\delta \hat{\delta}$ in population $R$. The analyses of the material which were made also showed that over the whole study period variations in dynamics of population numbers, 
the percentage of individuals recruited to the population, and those disappearing from it, sexually active males and females took place parallel to each other in all the plots of the given field.

It is clear from the above data that the groups of individuals occupying 0.5 ha plots formed one population within the given field.

\subsection{Dynamies of Numbers}

Increase in the number of voles was recorded from May to June in both populations during the first study year (Fig. 1). During July and August 1976 there was first a decrease, then an increase in the numbers

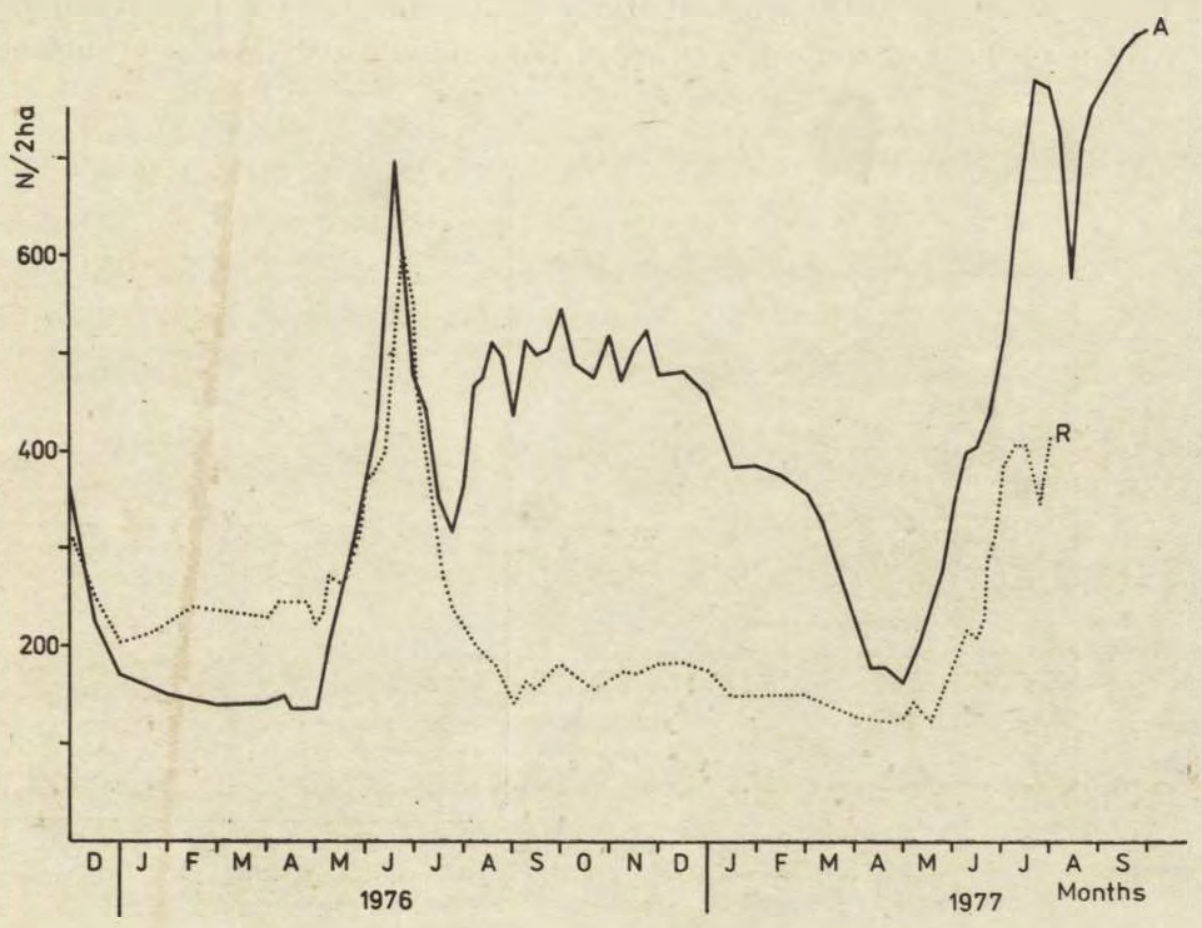

Fig. 1. Dynamics of numbers in the population occupying the alfalfa field (A) and winter rape field $(R)$.

of population $A$, and decrease in population $R$. In successive months, from September to November 1976, the level of numbers did not alter in either population, the numbers of population $A$ being twice higher than those in population $R$. During the winter from December 1976 to the end of April 1977, there was a decrease in the numbers of the population in the alfalfa field, while during the same period the numbers of voles living in the rape field remained almost unchanged, and thus numbers of the two populations were to a great degree balanced. During 
the further part of the experiment, from May to mid-July 1977, there was a renewed increase in the numbers of both populations.

Smaller numbers of population $A$ as compared with population $R$ were observed only during the period from December 1975 to May 1976 (Fig. 1). In May there was a greater increase in numbers in population $A$ than in $R$, and as from that time on the population in the alfalfa field was the more numerous.

Calculation was made separately for each population of the coefficient of correlation and linear regression for the relations between the rate of weekly variations in numbers $\left(\Delta N_{t}\right)$ and density of individuals per 2 hectares, which in the present study is the same as population numbers $\left(N_{t}\right)$. On account of the differences in the course of variations in numbers

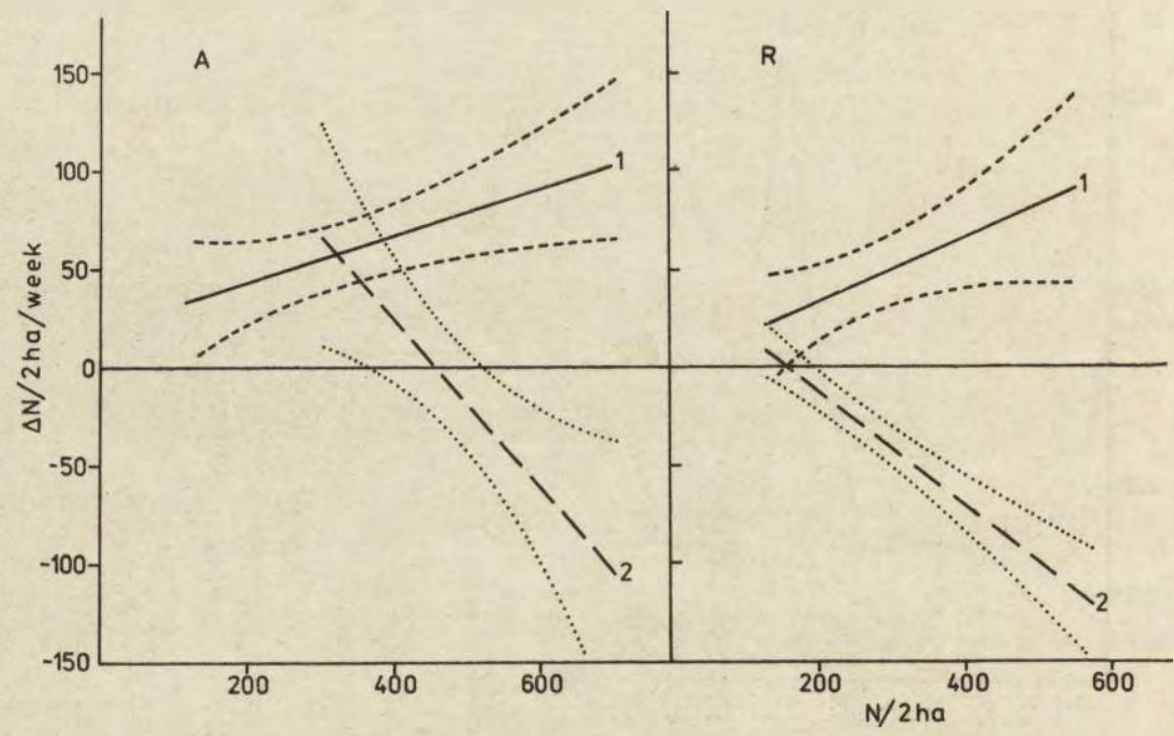

Fig. 2. Relation between weekly variations in numbers $\left(\Delta N_{t}\right)$ and numbers $\left(N_{t}\right)$ in populations $A$ and $R$.

Linear regression and $95 \%$ confidence intervals are shown for two periods:

1) period from May to June 1976 and from May to mid-July 1977 (period of increase in numbers) and

2) period from July to October 1976 (period of stabilized numbers), for which the regression equations are as follows:

$A$ (1) $N_{t}=0.1203 N_{t}+19.3551 ; r=0.5029^{1}$

$A(2) N_{t}=-0.4287 N_{t}+196.0808 ; r=-0.6052^{2}$

$R$ (1) $N_{t}=0.1612 \quad N_{t}-0.1933 ; r=0.4985^{1}$

$R(2) N_{t}=-0.2941 N_{t}+46.1485 ; r=-0.9801^{s}$

Statistical significance of coefficients of correlation $r$ was indicated: ${ }^{1} \alpha \leqslant 0.05$; ${ }^{2} \alpha \leqslant 0.01 ;{ }^{3} \alpha \leqslant 0.001$. 
during the year calculation were made for the periods: (1) May-June \$976 and May-mid-July 1977 jointly (part of the growing season in which sexually active females were recorded - see section 4.4. and increase in population numbers found). (2) July-October 1976 (remaining part of the growing season in which sexually active females were still found and no increase in numbers was observed). (3) December 1976 April 1977 (winter decrease in population numbers).

It is clear from the calculations that during the period of increase in population numbers (May-June 1976 and May--mid-July 1977) there was a positive relation between the weekly rate of increase in numbers and density in both populations (Fig. 2). During the period of stabilized numbers (July-October 1976), however, the weekly rate of increase declined in both populations together with increase in density (Fig. 2). During neither of these periods were statistically significant differences found in the intensity of the weekly rate of variations in numbers (measured by the coefficient of regression which defines the value of variations in density per one individual per week) between population $A$ and $R$.

During the period of a decrease in population numbers (December 1976 - April 1977) the weekly rate of variations in numbers did not depend on the density of individuals. At that time the mean values, for the whole of the winter period, of the weekly rate of decrease in numbers per individual $\left(\Delta N_{t} / N_{t}\right)$ was greater in population $A$ than in $R$ (differences statistically significant).

To sum up it may be said that (1) there was a decrease in numbers in the middle of summer in both populations, (2) three periods could be distinguished in the yearly cycle of the population number dynamics of both populations: increase, stabilization and winter decrease, (3) the population living in the alfalfa field was characterized by greater weekly rate of decrease in numbers in winter than the rape field population.

\subsection{Number of Individuals Recruited and Disappearing and Population Density}

Observations were made to determine how the processes of recruitment and disappearance of individuals proceeded during the periods of yearly variation in numbers, depending on population numbers and what connections there were between these processes and the weekly rate of variations in numbers.

The recruitment process was considered during the periods of increase and stabilization of numbers in relation to the number of sexually active females. It was found that during this time the number of sexually Acta Theriologica -3 
Table 1

Relation between number of sexually active females $\left(N_{f a t}\right)$ and number of all females $\left(N_{f t}\right)$ and population numbers $N_{t}$, and also rate of variations in numbers $\left(\Delta N_{t} / N_{t}\right)$ and number of disappearing $N_{u t}$ to the population occupying the alfalfa field $(A)$ and rape field $(R)$

All coefficients of correlation $r$ are statistically significant at confidence level $\alpha \leqslant 0.001$.

Linear regression equations

$\mathrm{r}$

Alfalfa field $(A)$

Increase in numbers (May - June 1976, May-mid-July 1977)

$N_{f a t}=0.7881 \quad N_{f t}-14.7285$

$N_{\text {fat }}=0.4800 \quad N_{t}-23.3809$

Period of stabilized numbers (July - Oct. 1976)

$N_{\text {fat }}=0.6466 \quad N_{f t}+20.2294$

$N_{\text {fat }}=0.4203 \quad N_{t}+12.3512$

$\Delta N_{t} / N_{t}=-0.1646 N_{u t}+20.1008$

0.9509

0.9482

0.7197

0.7202

Winter decrease in numbers (Dec. 1976 - April 1977)

$\Delta N_{t} / N_{t}=-0.0029 N_{u t}+0.0332$

$-0.8652$

Rape field $(R)$

Increase in numbers (May - June 1976, May-mid-July 1977)

$N_{f a t}=0.8611 \quad N_{f t}-29.9145$

0.9695

$N_{\text {fat }}=0.5198 \quad N_{t}-34.2898$

0.9723

$N_{\text {fat }}=0.9359 N_{f t}-45.2900$

$N_{\text {fat }}=0.6334 \quad N_{t}-55.1524$

$\Delta N_{t} / N_{t}=-0.1422 \quad N_{u t}+3.3483$

0.9482

$-0.7682$

Winter decrease in numbers (Dec. 1976 - April 1977)

$\Delta N_{t} / N_{t}=-0.0050 \quad N_{u t}+0.0261$

$-0.8617$

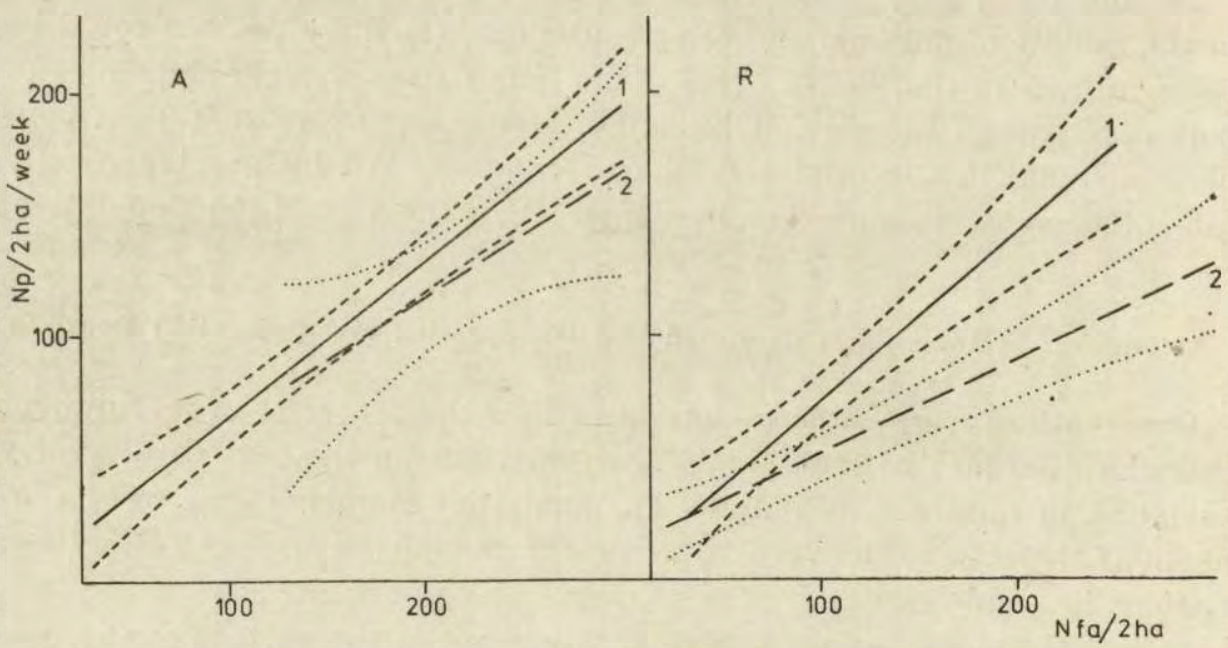

Fig. 3. Relation between number of recruited individuals $\left(N_{p t}\right)$ and number of sexually active females $\left(N_{f a t}\right)$ in populations $A$ and $R$.

Symbols as for Fig. 2. Explanation to Fig. 3 continued on page 171. 
$A(1) N_{p t}=0.6293 \quad N_{f a t}+5.0674 ; r=0.9269^{3} \quad R(1) N_{p t}=0.6926 \quad N_{f a t}+4.1146 ; r=0.8831^{3}$ $A(2) N_{p t}=0.5140 N_{f a t}+12.7968 ; r=0.5359^{1} \quad R(2) N_{p t}=0.3756 \quad N_{\text {fat }}+14.1676 ; r=0.8656^{3}$ Significance of correlation coefficients indicated as in Fig. 2.

active females $\left(N_{f a t}\right)$ in both populations was in proportion to the number of females $\left(N_{f t}\right)$ and also to the number of all individuals $\left(N_{t}\right)$ (Table 1).

In both populations the number of recruited individuals increased in direct proportion to the increase in the number of sexually active females (Fig. 3). Intensity of the recruitment (measured by the coefficient of regression, which defines the number of individuals recruited per one female per week) was similar in both periods in population $A$, but in population $R$ was greater during the period of increase in numbers than during the stabilization period. No statistically significant differences between population $A$ and $R$ were found in either period in respect of intensity of recruitment. In all cases the significance of differences was checked by means of the parallelism test. When the relation between rate of variations in numbers per individual $\left(\Delta N_{t} / N_{t}\right)$ and number of recruited individuals $\left(N_{p t}\right)$ was examined, no statistically significant correlations between these parameters were found in either period in population $A$ and $R$.

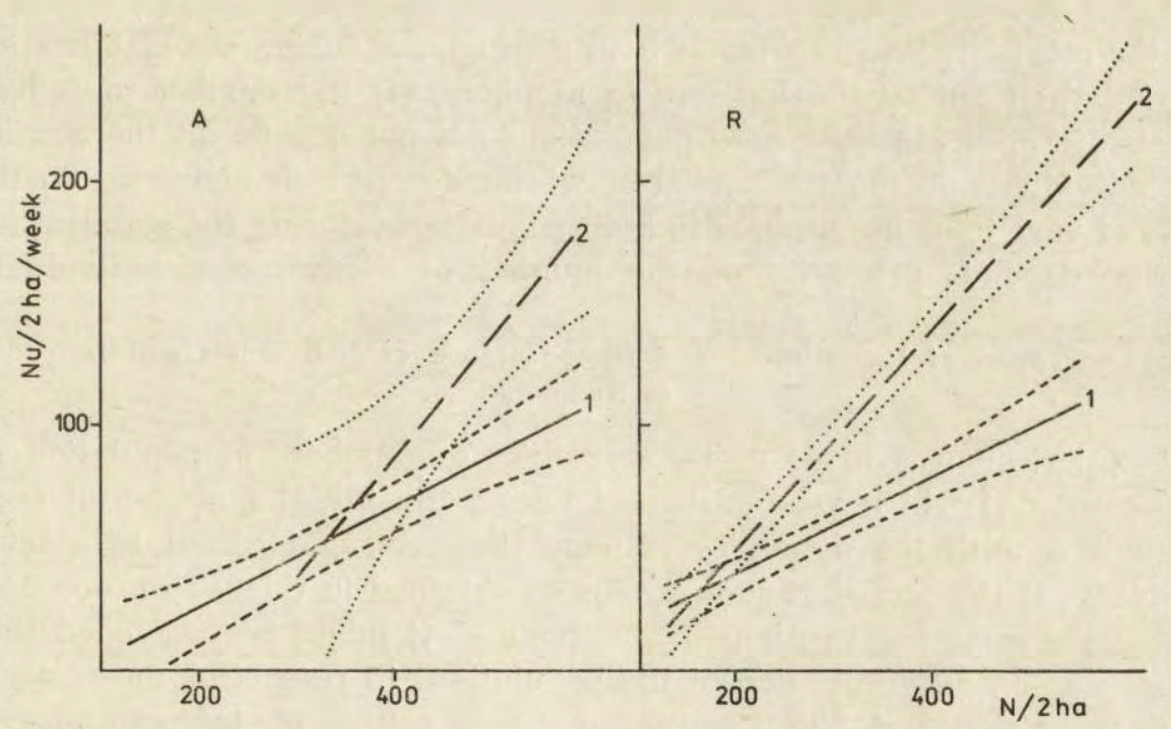

Fig. 4. Relation between number of disappearing individuals $\left(N_{u t}\right)$ and numbers $\left(N_{t}\right)$ in populations $A$ and $R$.

$A(1) N_{u t}=0.2091 \quad N_{t}-16.3128 ; r=0.8414^{3} \quad R(1) N_{u t}=0.1985 \quad N_{t}-0.7540 ; r=0.8787^{3}$

A(2) $N_{u t}=0.4918 N_{t}-109.4539 ; r=0.7045^{2} \quad R(2) N_{u t}=0.4497 \quad N_{t}-40.3303 ; r=0.9651^{\text {s }}$ Confidence levels for $r$ are: ${ }_{2} \alpha \leqslant 0.01,{ }^{3} \alpha \leqslant 0.001$. 
Analysis was next made of the process of disappearance of individuals from the population in relation to populations numbers, and the rate of variations in numbers separately for each of the periods distinguished. It was found that the number of individuals disappearing $\left(N_{u t}\right)$ was positively correlated with the density of individuals $\left(N_{t}\right)$ only during the period of increase and stabilization of numbers (Fig. 4). In both populations intensity of the disappearance (measured by the coefficient of regression, which defines the number of individuals disappearing per individual per week) was greater during the period of stabilization of numbers in comparison with the period of increase. A check was then made to ascertain whether the rate of variations in numbers per individual $\left(\Delta N t / N_{t}\right)$ depended on the number of individuals disappearing $\left(N_{u t}\right)$. The calculations made show that these relations took place in both populations not only during the period of winter decrease in their numbers, but also during the period of stabilized numbers (Table 1).

To sum up it may be said that: (1) The number of sexually active females increased in proportion to the number of all females in both populations during the period of increase and stabilization of numbers, (2) the intensity of the recruitment was similar in both periods in population $A$, but in population $R$ was lesser during the period of stabilization as compared with the period of increase in numbers, (3) intensity of the mortality was greater in both populations during the stabilization period than during the increase in numbers, (4) the number of individuals disappearing from both populations did not depend on the density of individuals during the period of winter decrease in numbers, (5) the rate of variations in numbers in both populations during the stabilization period depends primarily on the number of disappearing individuals.

\subsection{The Process of Recruitment and Disappearance of Individuals and Dynamics of Numbers}

Comparison was made of the dynamics of numbers of population $R$, the course of which was calculated taking the initial numbers of population $A$ with the dynamics of population $A$ standardized to a level of $100 \%$. If the course of such dynamics obtained in this way proceeded: (a) on the same level in both populations - it might be concluded that there was no differentiation of the populations in respect of the relation between $\% N_{p t}$ and $\% N_{u t}$ over the whole course of the experiment, (b) on a different level in each population, but during certain periods parallel to each other, that there was no differentiation of the populations in respect of the relation between $\% N_{p t}$ and $\% N_{u t}$ during the period when their course was parallel.

In the present studies a parallel course of dynamics in the two pop- 


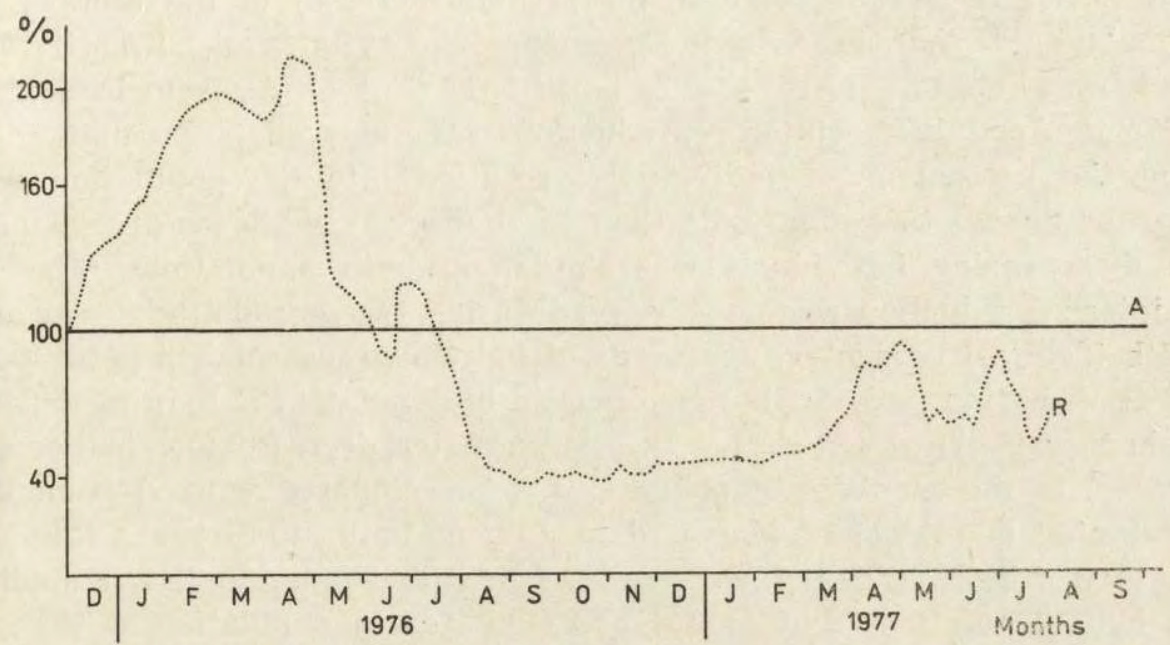

Fig. 5. Comparison of relative numbers $\left(\% N_{c t}\right)$ of population $R$ with numbers $\left(N_{t}\right)$ of population $A$ standardized to level of $100 \%$.

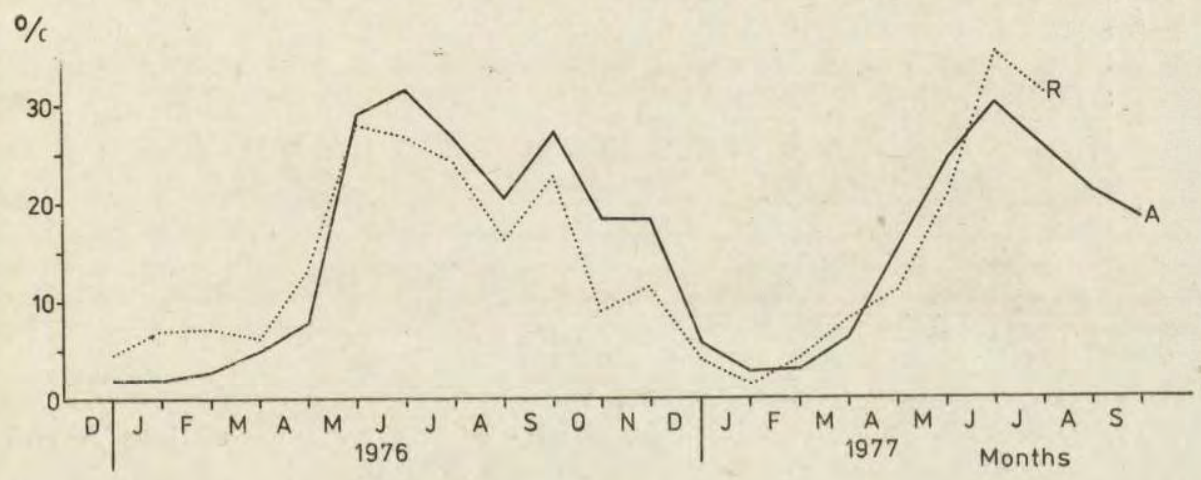

Fig. 6. Percentage of recruits $\left(\% N_{p t}\right)$ in populations $A$ and $R$ (weekly avarages in a month).

ulations was obtained during the period from August 1976 to January 1977 (Fig. 5). During this time the relations between $\% N_{p t}$ and $\% N_{u t}$ were thus similar in each population, the average percentage per week of recruited and disappearing individuals being greater in population $A$ than in population $R$ during the period from August to October (Fig. 6, 7). The above differences between mean values were statistically significant for the whole of the period discussed here.

During the remaining periods populations $A$ and $R$ differed as to the relation between recruitment and disappearance of individuals, which 
led to: (1) A smaller decrease (or greater increase) in the number of population $R$ than in $A$ from December 1975 to the end of April 1976 and from February to the end of April 1977 (Fig. 5). As from December 1975 to April 1976 winter reproduction was observed in population $R$, and the percentage of individuals recruited into the population was greater during this time in $R$ than in $A$ (Fig. 6), while the percentage of disappearing individuals was similar in both populations (Fig. 7). Winter reproduction was not observed during the second study year and with identical percentage of recruited individuals, a smaller percentage of disappearing individuals was observed in population $R$ than in $A$ from February to April 1977 (Fig. 7). (2) A greater decrease (or smaller increase) in the numbers of population $R$ as compared with $A$ from the beginning to middle of May and in July of both study years (Fig. 5). In May of both years the percentage of recruited individuals was similar in both populations, but in July was greater in population $A$ than $R$ (Fig. 6). During this time the percentage of disappearing individuals was always smaller in population $A$ than in $R$ (Fig. 7).

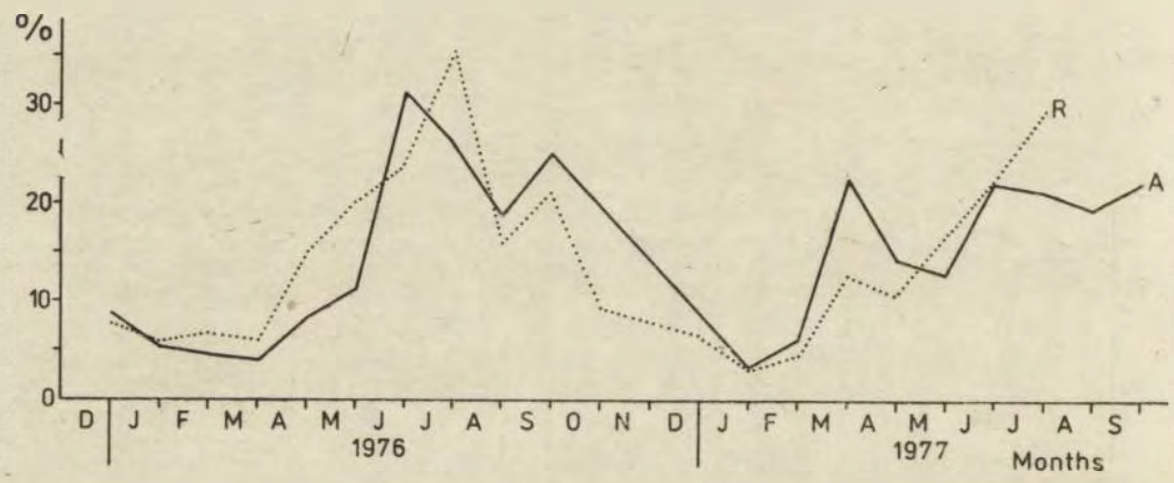

Fig. 7. Percentage of individuals disappearing $\left(\% N_{u t}\right)$ from populations $A$ and $R$ (weekly averages in a month).

To sum up it may be said that: (1) The differentiation in the numbers of voles living in different crops was chiefly due to the mortality rate among them. The mortality was lower among individuals living in the rape field $(R)$ than in the alfalfa field $(A)$ (if winter reproduction was not observed). During the growing season differences in mortality between populations occurred for a short time only (mid-May, July), and was greater at that time in population $R$ than in $A$. (2) During the period when the relation between recruitment and disappearance of individuals was similar in the two populations, the percentage of these two groups of individuals $\left(\% N_{p t}\right.$ and $\left.\% N_{u t}\right)$ was greater in population $A$ (with greater numbers) than in $R$ (with lesser numbers). 


\subsection{Percentage of Sexually Active Females}

Variations in the percentage of sexually active females over the year followed a similar course in both populations (Fig. 8), their mean proportion during the week from August to October 1976 being greater in population $A$ than in $R$. Differences between mean values for the whole of the period discussed here were statistically significant.

Bearing in mind the previously discussed relation of the recruitment of individuals and the number of sexually active females, it may be concluded that: the greater percentage of recruited individuals in population $A$ in comparison with $R$ may have been due, during the period from August to October 1976, to the greater percentage of sexually active females in population $A$.

\subsection{Percentage of Females in the Populations}

In both populations variations in the percentage of females took a similar course over the year (Fig. 9). In none of the periods of population

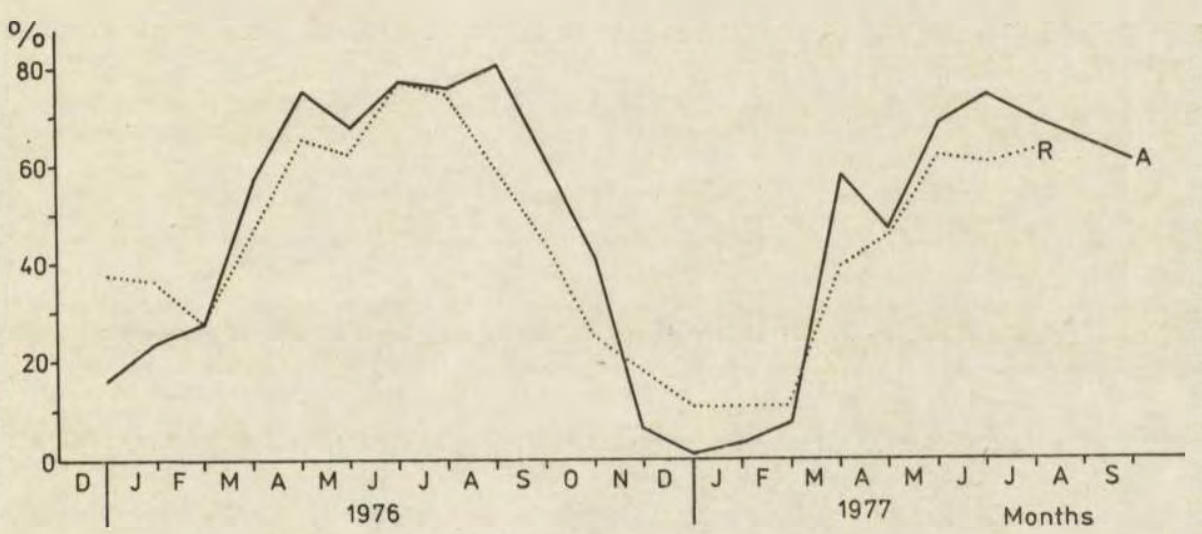

Fig. 8. Percentage of sexually active females $\left(\% N_{f a t}\right)$ in populations $A$ and $R$ (weekly averages in a month)

dynamics were statistically significant differences found between the mean percentage of females in population $A$ and $R$. In neither population $A$ nor $R$ during the increase and stabilization periods were statistically significant coefficients of correlation found between the number or percentage of recruited individuals and the percentage of females. It may therefore be said that the percentage of females was similar in both populations, and that changes in sex ratio had no direct effect on the recruitment of individuals, 


\section{DISCUSSION}

The demographic processes in a vole population are characterized by the rapid recruitment and disappearance of individuals, which gives them a marked capacity for regeneration (French et al., 1975; AdamczewskaAndrzejewska \& Nabagło, 1977). It must therefore be assumed that even considerable losses in numbers of voles are quickly made good, in the same way as in the case of studies on the effect of endrin in a population of $M$. pennsylvanicus (Morris, 1972). In the present studies the varied level of numbers in the populations occupying fields with different crops was maintained for a long period. In view of the foregoing I am of the opinion that, as in the studies on the community

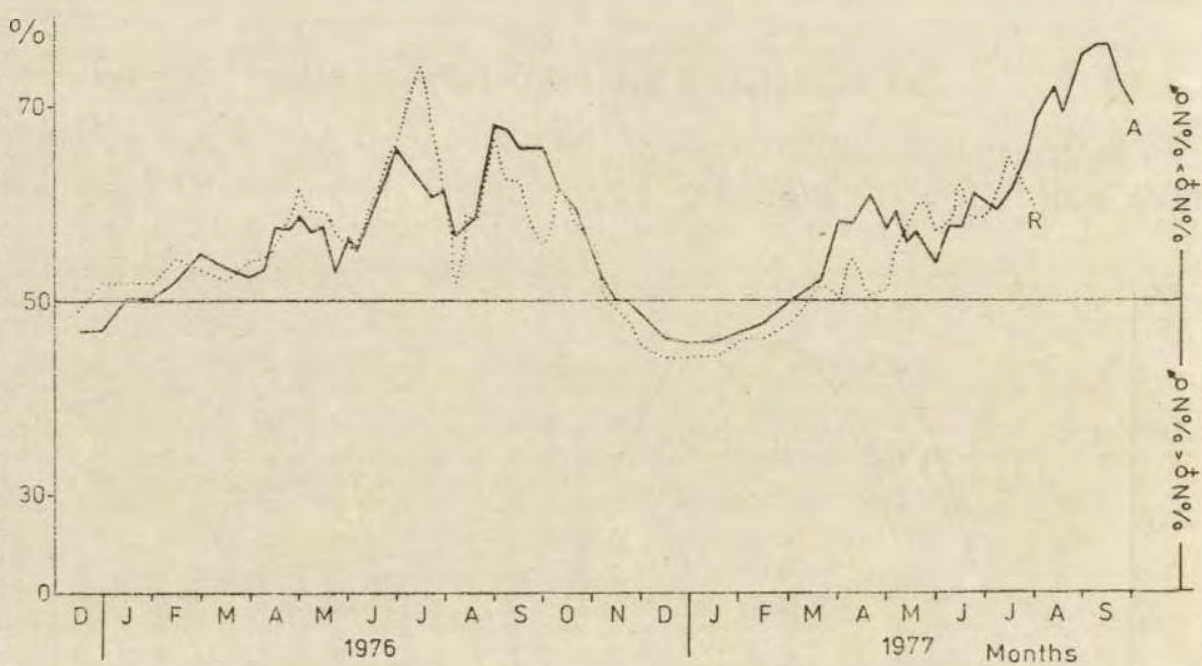

Fig. 9. Percentage of females $\left(\% N_{f t}\right)$ in populations $A$ and $R$.

of forest rodents (Mazurkiewicz \& Rajska-Jurgiel, 1979), in this case also the numbers of each population were adapted to the trophic conditions of the habitat, understood as the amount and quality of food available and the vegetation cover.

Analysis of reproduction showed that in both populations during the whole growing season the number of sexually active females was in proportion both to the number of all females and to population numbers. Similar results were obtained in studies on a free-living vole population (Adamczewska-Andrzejewska et al., 1979). During the period from August to October 1976 the percentage of sexually active females was greater in population $A$ (the numbers of which were greater) than in $R$ (with lower numbers), and thus depended on habitat conditions. It follows 
from this that in a population of $M$. arvatis the number of sexually active females is not maintained on a constant level during the reproduction period, as is the case in, for instance, the island population of C. glareolus (Bujalska, 1970). It may be that, like the results obtained by Frank (1953), limitation of the reproduction process in the common vole takes place only under the influence of unfavourable food conditions.

In these studies the number of recruited individuals was the result of reproduction, mortality in the nest and mortality during the period from leaving the nest up to the first capture. High mortality rate among young individuals is a general phenomenon. The results of laboratory studies (Walkowa \& Bujalska, 1977) also indicate that intensification of mortality among young voles up to the age of four weeks gradually increases in successive phases (growth, stabilization, decrease) of variations in numbers. In the present studies intensification of the recruitment was lesser during the stabilized phase than during the phase of increase in numbers only in population $R$, whereas in population $A$ it was similar in both phases. On account of the lack of simultaneous observations of litter size, it is difficult to determine with certainty what part the greater mortality among young individuals plays in reducing intensity of recruitment into population $R$ of individuals during the stabilized phase, and what part the smaller proportion, previously discussed, of sexually active females.

Variations in the percentage of females over the course of a year took place similarly in both the alfalfa and rape field populations. Consequently I conclude that the formation of sex structure in the vole population was to a considerable degree independent of habitat conditions. The mechanisms leading to changes in the sex ratio may in this case have been based on elimination of the weaker males by the stronger during the reproduction period, and the better capacity for survival of males than females at the end of reproduction, due to the lack of rivalry between males (Pelikán, 1959).

Opinions are divided among research workers as to the role of the sex ratio in forming vole population processes. On the one hand Stein (1953) and Poljakov (1964) consider variations in sex ratio as constituting an important mechanism shaping the dynamics of population numbers. Similarly Adamczewska-Andrzejewska \& Nabagło (1977) showed that during the year the recruitment of individuals is depended on the sex ratio in a confined population of $M$. arvalis. On the other hand Myers \& Krebs (1971) and Rose \& Gaines (1978) did not find any connections between sex ratio and population parameters. In the present studies, when separate analysis was made of the increase phase and stabilization 
phase of numbers, no simple connections were founc between recruitment and the percentage of females. The number of sexually active females in the study populations was in direct proportion to the number of all females, and therefore variations in sex ratio had an indirect effect on the reproduction.

Generally speaking, no intrapopulation mechanisms leading to inhibition of the reproduction process were found in the study populations of $M$. arvalis. The habitat conditions of the population, which were connected with the kind of crop, to some degree determined the course of the reproduction, forming proportions between the number of all females and the number of sexually active females appropriate to these conditions.

The number of disappearing individuals increased with increase in numbers in both populations. During the phase of increase in numbers intensity of disappearance was lesser than during the phase of stabilization. These results agree with the studies made by Spitz (1974), in which individuals born in spring were found to have a greater capacity for survival than those generations born later.

During the initial phase of the period of stabilized numbers the rise in mortality was so great that it caused a sudden drop in the numbers of population $A$ in July, and in population $R$ in July and August 1976. Adamczewska-Andrzejewska \& Nabagło (1977) consider the increased inroads of predators after the alfalfa was mown as one of the causes of this phenomenon. In the present studies the alfalfa was mown twice (at the beginning of June and towards the end of August), while a decrease in population numbers was observed only once during this period and was probably not connected with mowing the alfalfa. The decrease in numbers of the population living in the rape field began a month before the crop was mown and the field ploughed, and thus agrotechnical operations could not have initiated the decrease in numbers in this population. Harvesting of the rape crop and ploughing the field significantly altered the voles' food conditions, but this was only the cause of prolongation of decrease in the numbers.

Myllymäki (1977) connects the decrease in the population numbers of $M$. agrestis in the middle of summer with the increased mortality among old adults, as a result of the reduced protein contents in plants forming seeds at that time. During the flowering period alfalfa contains the smallest amount of protein (Plebański, 1970). The summer drop in numbers of the population living in this crop took place during the growth period of the second harvest, and the plants should therefore have been characterized by high protein content. On the other hand, however, in the rape field the plants at the time were in the phase of 
ripening seeds and might have contained smaller amounts of protein than young plants. On account, however, of the lack of appropriate studies on variations over the course of the year in protein contents in plants or parts of plants forming the basic food of voles, it is difficult fully to discuss Myllymäki's hypothesis (1977).

It would appear that the increase in mortality in the middle of summer may, in population $A$, and during the initial phase in population $R$, have been a manifestation of the reaction of the population organization to overcrowding of voles and only during the final phase to a change in habitat conditions (cf. also Petrusewicz, 1963, 1965, 1966, 1978). Preliminary grounds for this hypothesis can be supplied by the results of the studies by Dobrowolska et al. (1974) and Dobrowolska (1980), which show that during the yearly cycle it is in June and July that voles from both confined and free populations have a maximum level of leukocytes and lowest level of $\gamma$-globulin. This is evidence of the low effectiveness of the immunological system in $M$. arvalis during this time. In accordance with the theory put forward by Christian \& Davis (1964), such reaction may be a manifestation of the action of stress caused by strong social stimuli taking place with great density of rodents. In population $R$ an additional factor causing prolongation of the time of increased mortality among voles was the drastic change in habitat conditions caused by harvesting the crop and ploughing the field towards the end of July, and re-sowing the field with rape. The agrotechnical operations carried out changed not only the food supply for the population, but also limited the latter's living space to a great degree, as practically all that was left to the voles was the uncultivated grassgrown belts at the base of the walls. Re-occupation of the field took place successively towards the end of the growing season.

After the decrease in numbers in the middle of summer up to the end of the growing period, the level of numbers was different in each of the study populations, but in neither was subject to variation. No restriction of reproduction was recorded during this time and therefore mortality then acted as compensation in relation to recruitment, reducing to nil the rate of variations in numbers. This is evidence of the formation of dynamic equilibrium between reproduction and mortality with different levels of numbers depending on habitat conditions.

In view of the foregoing I conclude that, as in the case of other rodents (Bujalska, 1975; Rose \& Gaines, 1978), in the common vole population also mortality plays a greater part than reproduction in variation of numbers. In the phase of stabilized numbers the density-dependent increase in mortality in the middle of summer is of prime importance to the vole population. Possibly the density-dependent character of such 
mortality was due to the fact that the population was confined, and we should probably have observed increased migration of individuals, defined by Lidicker (1975) as saturated migration, in a free population. A result of increase in mortality in the middle of summer is the formation of a level of population numbers adequate to the given habitat conditions. It would appear that during this time basic changes are to be expected in the population organization, the more so as after the summer drop in numbers, equilibrium was observed to be maintained between reproduction and mortality. Malinowski (1980) concludes from studies made on the same populations that during this time intrapopulation mechanisms, connected with the defined norm for voles of intensity of inter-individual interactions, lie at the base of the compensatory action of mortality.

During the period from August to October 1976 the percentage of individuals recruited and disappearing were smaller in the population in the rape field (where numbers were smaller) than in the population in the alfalfa field (where numbers were greater). These results justify the conclusion that although the turnover of individuals is very great in M. arvalis populations (French et al., 1975; Adamczewska-Andrzejewska \& Nabagło, 1977), its rate depends on the habitat conditions under which the population lives. The above relation illustrates, in my opinion, the process of regulating expenditure costs for the population caused by change in habitat conditions.

During the winter mortality was greater in population $A$ than in $R$, and the number of disappearing individuals did not depend on population numbers. It follows from this that during this time it was chiefly habitat conditions which determined the voles' survival, including those connected with the kind of crop. It would therefore appear that the structure of crops may to some extent determine the number of overwintering individuals in a large area, which number, after Andrzejewski (1975), Gliwicz (1975), is to a great degree responsible for population numbers the following year.

The analyses made reveal a certain model of the way in which a confined population of voles functions during the growing season. Intrapopulation factors result in its being possible to distinguish a growth phase and stabilization phase in the course of variations in numbers, since: (1) the reproduction potential is in direct proportion to density; (2) the rate of recruitment of new individuals does not change with changes in density; (3) the mortality rate of individuals increases with increase in density; (4) changes in mortality rate with a constant recruitment rate lead to establishment of a balance in numbers. The population's habitat conditions, on the other hand, determine: (1) the 
level of balance in numbers; (2) the proportion of sexually active females in a population; (3) the turnover rate of individuals.

With reference to the discussion by Krebs \& Myers (1974) on the problem of whether quantity and quality of food may limit increase in population numbers of Microtinae, it must be said that these factors undoubtedly determine the level of variations in numbers in a population of common voles. Human activities in agrocenoses are aimed at achieving high plant production every year. Thus in the opinion of Krebs \& Myers (1974) food factors cannot be responsible for the cyclic character of fluctuations in numbers, but possible affect their amplitude. The studies on $M$. arvalis populations so far made indicate that further search for factors conditioning the cyclic character of fluctuations should be directed towards obtaining a knowledge of those factors which determine variations in intensity of mortality and not of reproduction.

Acknowledgements: I should like to express my grateful thanks to Dr S. M. Janion for his guidance during the course of these studies; to Drs K. Adamczewska-Andrzejewska, G. Bujalska, W. Malinowski, M. Mazurkiewicz and R. Mackin-Rogalska for their careful perusal of the paper, their critical remarks and discussion of the text; and to Ms. M. Plewka, and Messrs. K. Michalczyk, J. Pawelski, J. Renion and E. Mamaj, for their technical assistance.

\section{REFERENCES}

1. Adamczewska-Andrzejewska K. A., 1974: Prognozowanie zmian zagęszczenia nornika polnego (Microtus arvalis Pall.) w oparciu o pogłębioną analizę populacji. Biul. Inst. Ochr. Roślin, 57: 393-400.

2. Adamczewska-Andrzejewska K. A. \& Nabagło L., 1977: Demographic parameters and variations in numbers of the common vole. Acta theriol., 22: $431-457$.

3. Adamczewska-Andrzejewska K. A., Bujalska G. \& Mackin-Rogalska R., 1979: The dynamics of a rodent community in agrocenosis. Acad. pol. Sci. Cl. II., 9: $723-729$.

4. Andrzejewski R., 1969: Analiza wyników połowów drobnych ssaków metodą "kalendarza złowień". Zesz. nauk. IE PAN, 2: 1-104.

5. Andrzejewski R., 1975: Supplementary food and the winter dynamics of bank vole populations. Acta theriol., 20: 23-40.

6. Bashenina U. V., 1962: Ekologia obyknovennoj polevki, nekotorye čerty ej geografičeskoj izmenčivosti. Izd. Mosk. Univ. 1-309. Moskva.

7. Birney E. C., Grant W. E. \& Baird D. D., 1976: Importance of vegetative cover to cycles of Microtus. Ecology, 57: 1043-1051.

8. Bujalska G., 1970: Reproduction stabilizing elements in an island population of Clethrionomys glareolus (Schreber, 1780). Acta theriol., 15: 381-421.

9. Bujalska G., 1975: Reproduction and mortality of bank voles and the changes in the size of an island population. Acta theriol., 20: 41-56.

10. Chitty D., 1964: Animal numbers and behaviour. [In: Dymond J. R., ed. "Fish Wildlife: a Memorial to W. J. K. Harkness"]. Longmans Canada, 41-53. Don Mills. 
11. Christian J. J. \& Davis D. F., 1964: Endocrines, behaviour and population. Science, 164: 1550-1560.

12. Dobrowolska A., Rewkiewicz-Dziarska A., Szarska I. \& Gill J., 1974: Seasonal changes in hematological parameters, level of serum proteins and glycoproteins, activity of the thyroid gland, suprarenals and kidneys in the common vole (Microtus arvalis Pall.). J. interdiscipl. Cycle Res., 5, 3-4: 347-354.

13. Dobrowolska A., 1980: Seasonal changes of blood serum proteins of the common voles (Microtus arvalis Pall.). (in praep.)

14. Frank F., 1953: Untersuchungen über den Zusammenbruch von Feldmausplagen (Microtus arvalis Pallas). Zool. Jahrb. Abt., 3, 82: 95-136.

15. Frank F., 1954: Die Kausalität der Nagetier-Zyklen im Lichte neuer populationsdynamischer Unterschungen and deutschen Microtinen. Z. Morph. Okol. Tiere, 43: $321-356$.

16. French N. R., Stoddart D. M. \& Bobek B., 1975: Patterns of demography in small mammal populations. [In: Golley F. B., Petrusewicz K. \& Ryszkowski L., eds, "Small mammals: their productivity and population dynamics"]. 73-102. Cambridge Univ. Press.

17. Gladkina T. S., 1976: Logičeskaja model' dinamiki Čislennosti obyknovennoj polevki $\mathrm{v}$ Kaliningradskoj oblasti. Trudy VIZR, 50: 24-75. Leningrad.

18. Gliwicz J., 1975: Age structure and dynamics of numbers in an island population of bank voles. Acta theriol., 6: 275-295.

19. Grodziński W., Bobek B., Drożdż A. \& Górecki A., 1970: Energy flow through small rodent populations in a beech forest. [In: Petrusewicz K. \& Ryszkowski L., eds., "Energy flow through small mammal populations".J. 291-298. Warszawa.

20. Krebs C. J. \& Myers J. H., 1974: Population cycles in small mammals. IIn: Macfadyen A., ed., "Advances in Ecological Research".]. Acad. Press, 8: 267-339. London, New York.

21. Lidicker W. Z. Jr., 1975: The role of dispersal in the demography of small mammals. [In: Golley F. B., Petrusewicz K. \& Ryszkowski L., eds., "Small mammals: their productivity and population dynamics".]. 103-128. Cambr. Univ. Press.

22. Malinowski W., 1980: Struktury przestrzenne i grupowe populacji nornika na uprawach lucerny i rzepaku. (Praca doktorska).

23. Martinet L. \& Meunier M., 1969: Influence des variation saisonniéres de la luzerne sur la croissance, la mortalité et l'etablissement de la maturité sexuelle chez le Campagnol des champs (Microtus arvalis). Ann. Biol. anim. Biochem. Biophys., 9: 451-462.

24. Martinet L. \& Spitz F., 1971: Variations saisonniéres de la croissance et de la mortalité du Campagnol des champs, Microtus arvalis. Rôle du photopériodisme et de la végétation sur ces variations. Mammalia, 35: 38-84.

25. Mazurkiewicz M. \& Rajska-Jurgiel E., 1979: Size and structure of rodent community of various forest stand types. Bull. Acad. pol. Sci. Cl. II, 26: $669-677$.

26. Morris R. D., 1972: The effects of endrin on Microtus and Peromyscus. III. Enclosed field populations. Can. J. Zool., 50: 885-896.

27. Myers J. H. \& Krebs C. J., 1971: Sex rations in open and enclosed vole populations: demographic implications. Am. Nat., 105: 325-344.

28. Myllymäki A., 1977: Demographic mechanisms in the fluctuating populations of the field vole Microtus agrestis. Oikos, 29: 468-493. 
29. Naumov N. P., 1951: Novyj metod izučenija ekologii melkich lesnych gryzunov. Fauna i ekol. gryzunov, 4: 3-21.

30. Pelikán J., 1959: Rozmnožováni, populačni dynamika a přemnožovani hraboše polniho. [In: „Hraboš polni, Microtus arvalis” by J. Kratochvil et al.]. Ceskoslov. Akad. Ved, 130-179. Praha.

31. Petrusewicz K., 1963: Population growth induced by disturbance in the ecological structure of the population. Ekol. pol. A, 3: 87-125.

32. Petrusewicz K., 1965: Dynamika liczebności, organizacja i struktura ekologiczna populacji. Ekol. pol. B, 11: 299-316.

33. Petrusewicz K., 1966: Dynamics, organization and ecological structure of population. Ekol. pol. A, 14: 413-436.

34. Petrusewicz K., 1978: Osobnik, populacja, gatunek. Państw. Wyd. Nauk.: 1-384. Warszawa.

35. Petrusewicz K. \& Andrzejewski R., 1962: Natural history of a freeliving population of house mice (Mus musculus Linnaeus) with particular reference to groupings within the population. Ekol. pol. A, 10: 85-122.

36. Plebański T., 1970: Uprawa i użytkowanie lucerny. PWRiL, 1-176. Warszawa.

37. Poljakov I. Ja., 1964: Prognoz rasprostranienija vreditelej sel'skochozjajstvennych kul'tur. Izd. Kolos, 1-325. Leningrad.

38. Rose R. K. \& Gaines M. S., 1978: The reproductive cycle of Microtus ochrogaster in eastern Kansas. Ecol. Monographs, 48: 21-42.

39. Ryszkowski L., Goszczyński J. \& Truszkowski J., 1973: Trophic relationships of the common vole in cultivated fields. Acta theriol., 18: 125-165.

40. Schultz A. M., 1969: A study of an ecosystem: The arctic tundra. [In: Van Dyne G. M., ed., "The ecosystem concept in natural resource management".l. Academic Press, 77-93. New York, London.

41. Spitz F., 1974: Démographie du Campagnol des champs Microtus arvalis an Vendée. Ann. Zool. - Ecol. anim., 6: 259-312.

42. Stein G. W. H., 1953: Uber das Zahlenverhaltnis der Geschlechter bei der Feldmaus, Microtus arvalis. Zool. Jb. Syst., 82: 137-156.

43. Stenseth N. C., Hansson L. \& Myllymäki A., 1977a: Population dynamics of the field vole (Microtus agrestis L.): a model. EPPO Bull., 7: 371-384.

44. Stenseth N. C., Hansson L., Myllymäki A., Andersson M. \& Katila J., 1977b: General models for the population dynamics of the field vole Microtus agrestis in Central Scandinavia. Oikos, 29: 616-642.

45. Trojan P., 1970: Energy flow through a population of Microtus arvalis (Pall.) in an agrocenosis during a period of mass occurence. [In: Petrusewicz K. \& Ryszkowski L., eds., "Enegry flow through small mammal populations".]. Polish Sci. Publ., 267-279. Warszawa.

46. Walkowa W. \& Bujalska G., 1977: Natality and mortality in laboratory populations of Microtus arvalis (Pall., 1779). Bull. Acad. pol. Sci. Cl. II, 25: 295-299.

Accepted, January 28, 1981. 
Leszek NABAGEO

\section{PROCESY DEMOGRAFICZNE W ZAMKNIETEJ POPULACJI NORNIKA ZWYCZAJNEGO}

\section{Streszczenie}

W izolowanych na dwuhektarowych polach lucerny i rzepaku populacjach Microtus arvalis (Pallas, 1779) badano w jakim stopniu liczebność i zmiany parametrów demograficznych zależą od czynników środowiskowych związanych z gatunkiem uprawy a w jakim od uwarunkowań wewnątrzpopulacyjnych. Liczebność na polu lucerny była wyższa niż na polu rzepaku (Ryc. 1). Różnicowanie poziomów liczebności następowało przez zmiany w natężeniu śmiertelności (Ryc. 7). Od sierpnia do października $1976 \mathrm{w}$ populacji na polu rzepaku notowano abniżenie potencjału rozrodczego (Ryc. 8) i lepszą przeżywalność norników (Ryc. 7).

W dynamice liczebności obu populacji wyróżniono w ciągu roku okresy: 1. wzrostu; 2. stabilności; 3. zimowego spadku. Zależność tempa wzrostu liczebności od zagęszczenia miała w kolejnych okresach charakter dodatni, ujemny i brak zależności (Ryc. 2). Natężenie rekrutacji było w populacji na polu rzepaku mniejsze w okresie stabilności niż wzrostu liczebności, na polu lucerny podobne w obu okresach (Ryc. 3). Natężenie śmiertelności było w obu populacjach większe w okresie stabilności niż wzrostu (Ryc. 4). Zimą obserwowano większą śmiertelność norników na polu lucerny niż rzepaku.

Przedyskutowano sterujący charakter wpływu warunków środowiska na poziom liczebności i regulujący wpływ zagęszczenia na śmiertelność. Omówiono zmiany tempa rotacji osobników, odzwierciedlające elementy kosztów utrzymania populacji, w zależności od warunków środowiskowych. 